УДК 373.3:376-056.2

DOI: $\underline{10.35619 / \text { iiu.v2i11.226 }}$

Боровець Олена

кандидат педагогічних наук, доцент, доцент кафедри педагогіки початкової освіти Рівненського державного гуманітарного університету, м. Рівне, Україна ORCID: 0000-0002-0722-3317 e-mail: olena_borovets@ukr.net

\title{
ІНКЛЮЗИВНЕ НАВЧАННЯ В ПОЧАТКОВІЙ ШКОЛІ: ОРГАНІЗАЦІЙНО-ПЕДАГОГІЧНИЙ АСПЕКТ
}

Анотація. У статті розкривається сутність поняття «інклюзивне навчання» як спеціально організованого та керованого освітнього процесу взаємодії вчителя та учнів у закладі загальної середньої освіти, що грунтується на принципах недискримінації, врахування багатоманітності людини, ефективного залучення та включення до освітнього процесу всіх його учасників. Автор акцентує увагу на організаційно-педагогічних аспектах організації інклюзивного навчання в сучасній початковій школі.

Автор зауважує, що діти з особливими освітніми потребами в інклюзивному класі навчаються спільно з учнями нормативного розвитку, тому процес інклюзивного навчання організовується на принципах диференційованого та індивідуального підходу. Наголошується, що вчитель в інклюзивному класі планує власну діяльність, роботу асистента вчителя, навчальну діяльність усіх учнів. Зазначається, що залежно від особливостей освітніх потреб дитини (обмежені можливості здоров'я) створюються адаптована освітня програма, індивідуальний план розвитку та індивідуальний навчальний план учня.

У статті аналізується роль командної роботи фахівців з інклюзивної освіти у процесі організації інклюзивного навчання в початковій школі. Окреслено роль взаємодії вчителя та асистента вчителя у цьому процесі, оскільки кожен з них має свої обов'язки, а також обов'язки, які можуть бути спільними для них стосовно різних аспектів освітнього процесу. Проаналізовано обов'язки асистента вчителя, який разом із учителем класу здійснює соціально-педагогічний супровід дітей з особливими освітніми потребами.

Стверджується думка, що в умовах інклюзивного навчання кожній дитині, незалежно від фізичних чи психологічних особливостей, повинно забезпечуватися право на освіту та самореалізацію засобами комплексної допомоги висококваліфікованих фахівців.

Ключові слова: інклюзія, інклюзивне навчання, діти 3 особливими освітніми потребами, асистент учителя, взаємодія.

Постановка проблеми. Реалізація в системі освіти України гуманістичних та демократичних принципів передбачає задоволення прав кожної людини незалежно від іiі фізичних чи психологічних особливостей. Забезпечує можливість виконання такого завдання організація інклюзивного навчання в сучасних закладах загальної середньої освіти, що регламентується низкою нормативно-правових документів та законодавчих актів. Однак, практика запровадження інклюзії в українській освітній системі ще потребує ретельного вивчення та вирішення проблем, пов'язаних із труднощами у створенні якісного 
інклюзивного середовища, недостатністю теоретико-методичного забезпечення педагогів, часто неготовністю шкільних спільнот до прийняття ідей інклюзивної освіти тощо.

У контексті реалізації Концепції НУШ вважаємо актуальною проблему організації інклюзивного навчання в початковій школі, зокрема таких організаційно-педагогічних іiі аспектів, як організація спільного процесу учіння школярів нормативного розвитку та дітей з особливими освітніми потребами, взаємодія вчителя та асистента вчителя, застосування оптимальних форм та методів навчання учнів в інклюзивному класі.

Аналіз останніх досліджень 3 проблеми. Актуальність означеної проблеми в умовах реформування системи освіти в Україні активізувала наукові пошуки сучасних учених. Теоретичні основи інклюзивної освіти розробляються у працях Л. Будяк, А. Колупаєвої, Ю. Найди, Л. Савчук, О. Таранченко, 3. Шевців та інших. Особливості організації інклюзивного навчання в закладах освіти досліджують І. Дмитрієва, Л. Прядко, Т. Сак, Н. Софій, О. Федоренко та інші. Важливими для вирішення проблеми розроблення вимог до фахівців 3 інклюзивної освіти є праці, присвячені питанням підготовки педагогів до професійної діяльності в умовах інклюзивної освіти (В. Бондар, І. Садова, Т. Скрипник, 3. Шевців та інші).

Мета статті - охарактеризувати основні особливості інклюзивного навчання в початковій школі в організаційно-педагогічному контексті, проаналізувати специфіку організації процесу учіння школярів нормативного розвитку та дітей 3 особливими освітніми потребами в інклюзивному класі.

Виклад основного матеріалу дослідження. Одним із важливих завдань Нової української школи $є$ організація інклюзивного освітнього середовища, у якому забезпечуються права на освіту всіх без виключення дітей, незалежно від їхніх фізичних чи психологічних особливостей, де виявляються та усуваються фізичні, інформаційні та інші бар'єри (Бібік, 2017, с. 151). Саме в ефективно створеному інклюзивному освітньому середовищі можна якісно організувати інклюзивне навчання - процес здобуття освіти, в якому діти 3 особливими освітніми потребами навчаються в закладі освіти за місцем проживання разом з учнями нормативного розвитку. У працях 3. Шевців інклюзивне навчання тлумачиться як «спеціально організований та керований освітній процес взаємодії вчителя та учнів у закладі загальної середньої освіти, що грунтується на принципах недискримінації, врахування багатоманітності людини, ефективного залучення та включення до освітнього процесу всіх його учасників» (Шевців, 2019, с. 134).

Учитель сучасної початкової школи повинен бути готовим до прийняття у клас дітей 3 особливими освітніми потребами. Згідно Закону України «Про освіту», дитина 3 особливими освітніми потребами - це особа, яка потребує додаткової постійної чи тимчасової підтримки в освітньому процесі з метою забезпечення ії права на освіту (Міністерство освіти і науки України, 2017), тобто це не лише особи 3 обмеженими можливостями здоров'я, 3 інвалідністю, але й учні з особливими мовними освітніми потребами, внутрішньо переміщені, діти-сироти тощо. Працюючи в інклюзивному класі, педагогові необхідно враховувати специфіку соціальної ситуації розвитку кожного учня, забезпечувати умови для формування вміння вчитися всіх школярів, для спілкування дітей молодшого шкільного віку, зважати на нерівномірність підготовленості й індивідуального фізичного, психологічного розвитку дітей цієї вікової категорії (особливо першокласників), враховувати різну динаміку процесу формування вмінь та навичок учнів початкової школи.

Діти з особливими освітніми потребами в інклюзивному класі навчаються спільно 3 учнями нормативного розвитку, тому їх необхідно залучати до різних форм та методів навчально-пізнавальної діяльності. Залежно від особливостей освітніх потреб дитини 
(обмежені можливості здоров’я) створюється адаптована освітня програма - «освітня програма, модифікована для навчання осіб 3 обмеженими освітніми можливостями 3 урахуванням особливостей їх психофізичного розвитку, індивідуальних можливостей, яка забезпечує корекцію порушень розвитку та соціальну адаптацію зазначених осіб» (Шевців, 2019, с. 94).

Реалізація такої програми зумовлює необхідність адаптації навчальних підручників, посібників, застосування спеціальних засобів навчання. Для учнів з особливими освітніми потребами створюються індивідуальний план розвитку та індивідуальний навчальний план, у якому передбачається проведення корекційно-розвивальних занять. У процесі укладання та реалізації індивідуального плану розвитку та індивідуального навчального плану дитини вчителі початкової школи послуговуються спеціальною комплексною допомогою різних фахівців (спеціалістів у галузі корекційної педагогіки, психологів, медичних працівників).

В організації інклюзивного навчання, вирішенні його завдань і цілей педагогові допомагає асистент учителя, який повинен разом з учителем забезпечувати виконання навчальної програми та допомагати учням з особливими освітніми потребами набувати знань, вмінь та навичок, що будуть їм необхідні для повноцінного життя в класі, школі, суспільстві. У своїй професійній діяльності асистент учителя керується нормативноправовими документами, зокрема Листом Міністерства освіти і науки, молоді та спорту №1/9-675 від 25.09.2012 року «Щодо посадових обов’язків асистента вчителя» (Міністерство освіти і науки, молоді та спорту, 2012).

У процесі професійної взаємодії вчитель та асистент учителя мають кожен свої обов'язки, а також обов'язки, які можуть бути спільними для них стосовно різних аспектів освітнього процесу (оцінювання розвитку дитини, планування, контроль дисципліни, організація процесу навчання, оцінювання навчальних результатів). Так, наприклад, у процесі оцінювання розвитку дитини, до обов'язків учителя належить визначення навчальних потреб, внесення пропозицій щодо прийняття рішень, вибір 3 наявних альтернатив. Обов'язки асистента вчителя - спостереження за поведінкою учня й надання інформації вчителям, надання пропозицій вчителям щодо виконання можливих дій i безпосередніх послуг (наприклад, логопедичних). Спільні дії вчитедя та асистента вчителя включають обговорення здібностей учнів, їхніх сильних і слабких сторін, участь у засіданнях $з$ питань планування, обговорення очікуваних навчальних результатів учнів, обговорення навчальних, поведінкових та емоційних цілей для дитини.

Під час організації освітнього процесу в обов'язки вчителя входить планування i проведення навчальних занять, діагностика та оцінка результатів процесу навчання й надання учням допомоги, забезпечення необхідними матеріалами асистента вчителя. Обов'язки асистента вчителя - більш детальне пояснення елементів уроку тим учням, в яких виникають проблеми, контроль виконання вправ на закріплення, запровадження спеціальних методів на вимогу вчителя, контроль освітнього процесу, ведення записів i надання звітів учителеві. Спільні дії - це обговорення та з'ясування очікуваних результатів, обговорення окремих навчальних стратегій, дій і результатів (Дятленко та ін., 2015, с. 4446).

Разом із учителем класу асистент учителя здійснює соціально-педагогічний супровід дітей з особливими освітніми потребами. Якщо така дитина не може виконувати певні види діяльності самостійно, асистент учителя повинен: допомагати учням 3 фізичними порушеннями та обмеженою мобільністю під час виконання фізичних вправ і під час пересування, організовувати безпечне довкілля для задоволення потреб дітей у сфері особистого догляду, допомагати учням у виконанні щоденних побутових завдань. Асистент 
учителя сприяє організації взаємодії вчителя з учнем через усунення канцелярських, технічних та інших бар'єрів. Важливими завданнями діяльності асистента вчителя $€$ сприяння соціальній, емоційній та когнітивній адаптації кожної дитини до освітнього простору школи, щоб вона відчувала себе повноцінним учасником шкільного і суспільного життя.

Організовуючи навчальні заняття в інклюзивному класі, педагог повинен реалізувати принцип індивідуального підходу до всіх учнів, зокрема і до учнів з особливими освітніми потребами: адаптовувати навчальний матеріал, використовувати спеціальні прийоми та засоби навчання, обирати оптимальний темп роботи. Наприклад, Т. Сак рекомендує диференціювати навчальний матеріал для дітей з особливими освітніми потребами на три основні групи: 1) те, що дитина повинна засвоїти обов'язково; 2) те, що дитина має знати; 3) те, що дитина може знати (Сак, 2014).

Під час уроку в інклюзивному класі вчитель організовує і управляє учінням усіх учнів, включаючи їх в активну навчальну діяльність. За необхідності учням 3 особливими освітніми потребами ставляться різні завдання, але при цьому їх залучають до групової командної роботи, до участі в іграх, до підготовки проєктів, проведення різноманітних досліджень тощо. У працях Л. Прядко наведено низку рекомендацій щодо використання прийомів навчання, що сприятимуть ефективній організації процесу навчання. Авторка пропонує використовувати кількаразове повторення завдань, пропонувати альтернативні способи виконання завдань, користуватися зразками та алгоритмами, проводити вправи 3 коментуванням, чергувати прості і складні завдання тощо (Прядко, 2018).

Проєктуючи навчальне заняття в інклюзивному класі, педагог планує власну діяльність, роботу асистента вчителя, навчальну діяльність усіх учнів, враховуючи можливості застосування диференційованого підходу та необхідності корекційної спрямованості навчання дітей з особливими освітніми потребами. Під час уроку вчитель повинен тримати в полі зору всіх школярів і оперативно орієнтуватися, якщо потрібно внести зміни в попередньо спланований хід заняття.

Сучасні дослідники сходяться на думці, що важливою умовою ефективної організації процесу навчання в інклюзивному класі $€$ високий рівень професійної інклюзивної компетентності педагогів, володіння ними спеціальними знаннями та навичками, вміннями співпрацювати в команді фахівців з інклюзивної освіти.

Висновки і перспективи подальших розвідок. Аналіз джерел з означеної проблеми дає підстави стверджувати, що інклюзивне навчання - це така спільна діяльність учителя 3 учасниками освітнього процесу, яка забезпечує розвиток та соціалізацію всіх учнів, засвоєння ними базових компетентностей, формування рис і якостей особистості. В умовах інклюзивного навчання кожній дитині, незалежно від фізичних чи психологічних особливостей, повинно гарантуватися право на освіту та самореалізацію засобами комплексної допомоги висококваліфікованих фахівців. Ефективність інклюзивного навчання визначається низкою педагогічних умов, які потребують грунтовного вивчення та розроблення науково-методичного забезпечення, що вважаємо перспективними напрямами подальших досліджень.

\section{СПИСОК ВИКОРИСТАНИХ ДЖЕРЕЛ}

Бібік, Н. (2017). Нова украӥнська школа: порадник для вчителя. Київ: ТОВ «Видавничий дім «Плеяди». 206 с.

Шевців, 3. (2019). Основи інклюзивної педагогіки. 2-е вид. Львів: «Новий світ - 2000». $264 \mathrm{c}$. 
Міністерство освіти і науки України, (2017). Закон України «Про освіту». URL: https://zakon.rada.gov.ua/laws/show/2145-19 [Дата звернення 01 березня 2020].

Міністерство освіти і науки, молоді та спорту, (2012). Лист Міністерства освіти $i$ науки, молоді та спорту №1/9-675 від 25.09.12 року «Щодо посадових обов `зків асистента вчителя».URL: https://osvita.ua/legislation/Ser_osv/32125/ [Дата звернення 21 лютого 2020].

Дятленко, Н., Софій, Н., Мартинчук, О, Найда, Ю. (2015). Асистент учителя в інклюзивному класі. Київ: Плеяди, 172 с.

Сак, Т. (2014). Диференційований підхід до навчання учнів 3 особливими освітніми потребами. Науковий часопис НПУ імені М. Драгоманова. Серія: Корекиійна педагогіка та спеціальна психологія, 26, с. 215-219.

Прядко, Л. (2018). Проблема організації уроку в інклюзивному закладі освіти. Актуальні питання корекційної освіти, 11, с. 264-273.

\section{REFERENCES}

Bibik, N. (2017). Nova ukrainska shkola: poradnyk dlia vchytelia [New Ukrainian School: Teacher Advisor]. Kyiv: TOV "Vydavnychyi dim "Pleiady". 206 s. (in Ukrainian)

Shevtsiv, Z. (2019). Osnovy inkliuzyvnoi pedahohiky [Fundamentals of Inclusive Pedagogy]. 2-e vyd. Lviv: "Novyi svit - 2000". 264 s. (in Ukrainian)

Ministerstvo osvity i nauky Ukrainy, (2017). Zakon Ukrainy "Pro osvitu" [Law of Ukraine "On Education”]. URL: https://zakon.rada.gov.ua/laws/show/2145-19 [Data zvernennia 01 bereznia 2020]. (in Ukrainian)

Ministerstvo osvity i nauky, molodi ta sportu, (2012). Lyst Ministerstva osvity i nauky, molodi ta sportu №1/9-675 vid 25.09.12 roku «Shchodo posadovykh obov iazkiv asystenta vchytelia» [Instruction from the Ministry of Education and Science, Youth and Sports No1 / 9-675 dated 25.09.12 "On the Duties of Teacher Assistant”]. URL: https:/osvita.ua/legislation/Ser_osv/32125/ [Data zvernennia 21 liutoho 2020]. (in Ukrainian)

Diatlenko, N., Sofii, N., Martynchuk, O, Naida, Yu. (2015). Asystent uchytelia v inkliuzyvnomu klasi [Teacher' Assistant in an Inclusive Class] Kyiv: Pleiady, 172 s. (in Ukrainian)

Sak, T. (2014). Dyferentsiiovanyi pidkhid do navchannia uchniv z osoblyvymy osvitnimy potrebamy [Differentiated Approach to Teaching Students with Special Educational Needs]. Naukovyi chasopys NPU imeni M. Drahomanova. Seriia: Korektsiina pedahohika ta spetsialna psykholohiia, 26, s. 215-219. (in Ukrainian)

Priadko, L. (2018). Problema orhanizatsii uroku v inkliuzyvnomu zakladi osvity [Issue of Organizing a Lesson in an Inclusive Educational Institution]. Aktualni pytannia korektsiinoi osvity, 11, s. 264-273. (in Ukrainian)

\section{INCLUSIVE EDUCATION IN ELEMENTARY SCHOOL: ORGANIZATIONAL AND PEDAGOGICAL ASPECT}

Olena Borovets

Candidate of Pedagogical Sciences, Associate Professor, Associate Professor at the Department of Primary Education Pedagogy, Rivne State University for the Humanities, Rivne, Ukraine ORCID: 0000-0002-0722-3317 e-mail: olena_borovets@ukr.net 


\begin{abstract}
The article reveals the essence of the concept of "inclusive education" as a specially organized and managed educational process of interaction between teachers and pupils in the institution of general secondary education, based on the principles of non-discrimination, taking into account the diversity of people, effective involvement and inclusion in the educational process of all its participants. The author focuses on organizational and pedagogical aspects of the organization of inclusive education in the modern primary school. Therefore, in the context of the implementation of the "New Ukrainian School" Concept, the creation of an inclusive educational environment, the effective functioning of which is characterized by a set of pedagogical, psychological and sociological conditions, is of great importance.

The author notes that children with special educational needs in an inclusive class learn together with pupils of normative development, therefore the process of inclusive learning is organized on the principles of differentiated and individual approach. It is emphasized that the teacher in the inclusive class plans his own activity, the work of the teacher's assistant and the educational activities of all pupils. It is noted that depending on the particular educational needs of the child (a disability), a tailored educational program, individual development plan and individual curriculum of a pupil were created.

The article analyzes the role of teamwork of inclusive education professionals in the process of organizing inclusive education at primary school. The role of interaction between a teacher and a teacher's assistant in this process was outlined as they each have their own responsibilities as well as responsibilities that may be shared by them regarding different aspects of the educational process. The duties of a teacher's assistant, who together with a class teacher provides social and pedagogical support for children with special educational needs, were analyzed.

The author states the idea that in an inclusive learning environment, every child, regardless of physical or psychological characteristics, should realize the right to education and self-realization by means of comprehensive assistance from highly qualified specialists.
\end{abstract}

Keywords: inclusion, inclusive education, children with special educational needs, teacher's assistant, professional interaction.

Стаття надійшла до редакиї 15.04. 2020 р. 